\section{SOI: 1.1/TAS DOI: 10.15863/TAS \\ International Scientific Journal Theoretical \& Applied Science}

Asliddin Fazliddinovich Sultonov

Researcher

National University of Uzbekistan Tashkent, Uzbekistan asl-sher@mail.ru

p-ISSN: 2308-4944 (print) e-ISSN: 2409-0085 (online) asl-sulton@umail.uz

Year: $2016 \quad$ Issue: $10 \quad$ Volume: 42

Published: $30.10 .2016 \quad$ http://T-Science.org

SECTION 30. Philosophy.

\title{
MODERN MANAGEMENT IN GOVERNMENT: A PHILOSOPHICAL APPROACH
}

Abstract: The article analyzes the essence of management, its purpose and objectives. Comparing the existing theoretical concepts of management, the author is critical of them, constructively synthesizes them and tries to develop management theory.

Key words: Management essence; stability and development; management tasks.

Language: English

Citation: Sultonov AF (2016) MODERN MANAGEMENT IN GOVERNMENT: A PHILOSOPHICAL APPROACH. ISJ Theoretical \& Applied Science, 10 (42): 34-38.

Soi: http://s-o-i.org/1.1/TAS-10-42-8 Doi: crossef http://dx.doi.org/10.15863/TAS.2016.10.42.8

\section{Introduction}

\section{Sidedness definition}

Despite the fact that the "governance" is a socio-philosophical concept and a universal phenomenon, today it is mainly against the background of the classical theories of management, longer applies in the economic sphere (management). If you pay attention to the theoretical definition of the phenomenon, it is clear that the economic understanding and definition of administrative activity strong point in favor of its functional features. Do not ignore the importance of this approach, it is appropriate to say that science remain open questions such as "what is the essence of management", "especially its manifestations in the socio-political sphere", "effective methods and criteria of managerial capacity" in the government as a whole, and in particular. Naturally, this implies different problems of state-organizational (administrative) character. In other words, it is the lack of a clear scientific view on the universal administrative activity allowed the different mistakes in practice.

With the formation of social relations, especially the emergence of the state to the present stage of human development to the management of interest continues to grow. In the course of solving management problems made the appropriate practical conclusions, theoretical considerations of humanity, that is, accumulated great spiritual heritage, which resulted in the XX century, having three separate sciences, specifically studying this phenomenon.
First, is "Political Science" in social science that studies the political system, the second "Cybernetics", which studies issues of control of technical systems, and the third is economic "Menagement". Today, against the backdrop of development of scientific knowledge there is a need to better explain the meaning and the essence of management.

The fact that there is some uncertainty about the meaning and substance of the management in the world today. For example, most theorists of this sphere in the definition and description of management based on the functions that are used in this activity. In particular, representatives of Taylor's scientific management, G.Emerson, classical or administrative A. Fayolle, Weber, G.Ford, modern systematic management of G.Saymon, Ch.Bernard and others who have developed many concepts in this direction based on the control functions. According to this, today every management seems to be an activity in which you are planning, organization, coordination, mobilization and monitoring (controlling) [1] .

\section{Management in philosophy}

Of course, these functions of management are an important. But this does not give grounds for believing that they express the essence of management. For the essence of all activities (phenomena, processes) is determined not to perform tasks and the expected result suggesting the objectives and significance of its existence. In other words, factors such as the purpose and aim determine 
the essence. Thus, the essence of management is detected within the meaning and purpose of the activity. The functions are only express management sense. From the above it follows that to date most of the "Control" are based on the definitions of the functions and tasks. It characterized by its content, and not the essence. When comprehension of the true essence of management, it is not always taken into account the value or purpose. To fill this vacuum, we will closer look at this aspect of management. For philosophy - it is primarily of nature.

In cybernetics, defined as the science of the processes and control system, control system and collect art information processing and transmission of information of a certain system (social, natural, technical) by ordering process modeling [2]. Hence, management is describes considered in conjunction ordering system in cybernetics. In our opinion, such a statement of objectives is not unreasonable. First, the life is decently built and required to obey the order, and secondly, this pattern was recognized and deeply studied by many thinkers.

In particular, this need comprehensively explained in the political-philosophical concepts. Studying the fundamental works of management and the government, many of these concepts see its relevance to the need to ensure stability and order in the system. For example, Confucius' disciple, classic ancient Chinese philosopher Xiong Zhi (298-238 BC) explains this point as follows: "Man seek profitability and growth, it forms a competition among them, psychology does not concede to each other, as well as man is by nature a cruel. He has an innate sense of envy. To offend people is because it lays on human nature. Following this behavior engenders confusion and chaos appears in the state. After all, the state is alive only because it eliminates the riots." [3.]

The Roman philosopher Titus Maktsy Plautus (254-184 BC) is expressed even more sharply. According to him, "Men are wolf to each other." [4] Thomas Hobbes (1588-1679 gg) formulated these statements of Plautus as a "war of all against all." [5] On the basis of this, it appears that when faced interests of the people, they come relentlessly, if you give them the will, the strong come to "destroy" the weak. Hence, management appears to maintain order.

We also know the views of prominent thinkers of the Central Asian region. For example, Abu Nasr Farabi notes that "the task of the state is educate in human dignity and courtesy and protect them from immorality." Ibn Sina in his work "Donishnoma" sets out the scientific and practical views on the management of the state and its methods. According to his philosophy, "science is divided into 3 types: the first - the science of managing people for the unconditional observance of order and discipline in society, is a science and is divided into two kinds: the first - what are the existing conditions and instructions, the second, on what should be policy. If the first one is the main, the second is its branch and the result. Second science is management of household, namely, the ordering of relations between husband and wife, father and son, boss and servant. The third science is the human, as he manages to himself." [6]

The great encyclopedist Abu Rayhan Biruni (973-1048 gg.) writes that, management and governance is the fatigue of his body for the protection of a citizen family, his property and life conduct of the war to protect the citizen, selfsacrifice for the preparation of a means to protect it. [7]

Islamic scholar Abu Hamid Ghazzali (10581111), too, thinks so: "Because there is need society between people. Some are not satisfied with what and how to eat, cause harm to others, because of which there is the need for three things. One of them is power and politics, justice and other state, and the third fiqh, through which the rule of law applied to the people." [8]

According to the political and philosophical views of the great thinker of the era Timurids, Alisher Navoi (1441-1501), there is a need to divide people into two types, as they have different characters. If some people are wise, smart and conscientious, most of them are ignorant, ignorant of anything. To educate the dark minds of such people God sent his prophet as an ambassador. He also issued laws to these people knew how to behave and kings sent to the managed them. [9] Also, Hussein Voiz Koshify (1442 / 46-1505) considers that "the real purpose and power of the state - is the protection of people and the improvement of the country." [10]

This view of the importance of control occurs even in the European philosophical concepts of new epoch. For example, the German philosopher Immanuel Kant (1724-1804) thinks that, although the laws were made to protect against external threats, people by nature tend to avoid them, in such cases, when there is an injustice, to the rights and freedom of others, emerged the state for coercive measures standards. [11]

Modern scholars have put forward the validity of the above mentioned views on the prevention of social conflicts in government, society and the importance of the stability of the established order. Professor S.Atamuratov writes that political governance is the process of organizing the political system. Political control, its content is the process of preventing deviations society life. It gives stability of the political system and maintains the balance between the political, economic, social and spiritual system of society. [12]

\section{Purposes of management}

Becomes clear that the need for policy and management took a firm place in the philosophical thinking. Most scientists and philosophers believe 
that if unleash natural stereotype people is a ruthless struggle for their goods, and this leads to serious social consequences. It is necessary to manage the company to avoid such ignorance in society. In this sense, the main purpose is to provide stability of control, safety and internal system order.

Indeed, any system control, above all, aimed at preserving the system. Therefore, the essence and nature of control is existential and conservative. In philosophy, it is assumed that the existence of a state system for ensuring the constancy of interconnection elements. If the existence of the natural does not require subjective factor, it is objectively exists, but an existence in the public system is not possible without human factor. The reason for this is that a strong and large social system can attach themselves weak and is a threat to its existence. In short, to ensure the existence of a social system depends on sound management. Even the long existence of the social system is possible due to management activities.

Despite this reality, be limited to this control character, and concentrate only on this, several narrows its essence. The question then becomes, "What are some goals that case management"? In our view, along with the preservation, protection from internal and external threats to stability, the development occupies an important place in management activity. For, while the evaluation of executives and management personnel, in the opinion of the people or employees, it is not enough to live only in conditions of stability. On the contrary, to focus only on the provision of stability and security, and at the same time, if there is no qualitative change or can not see them, then have to abandon such leaders.

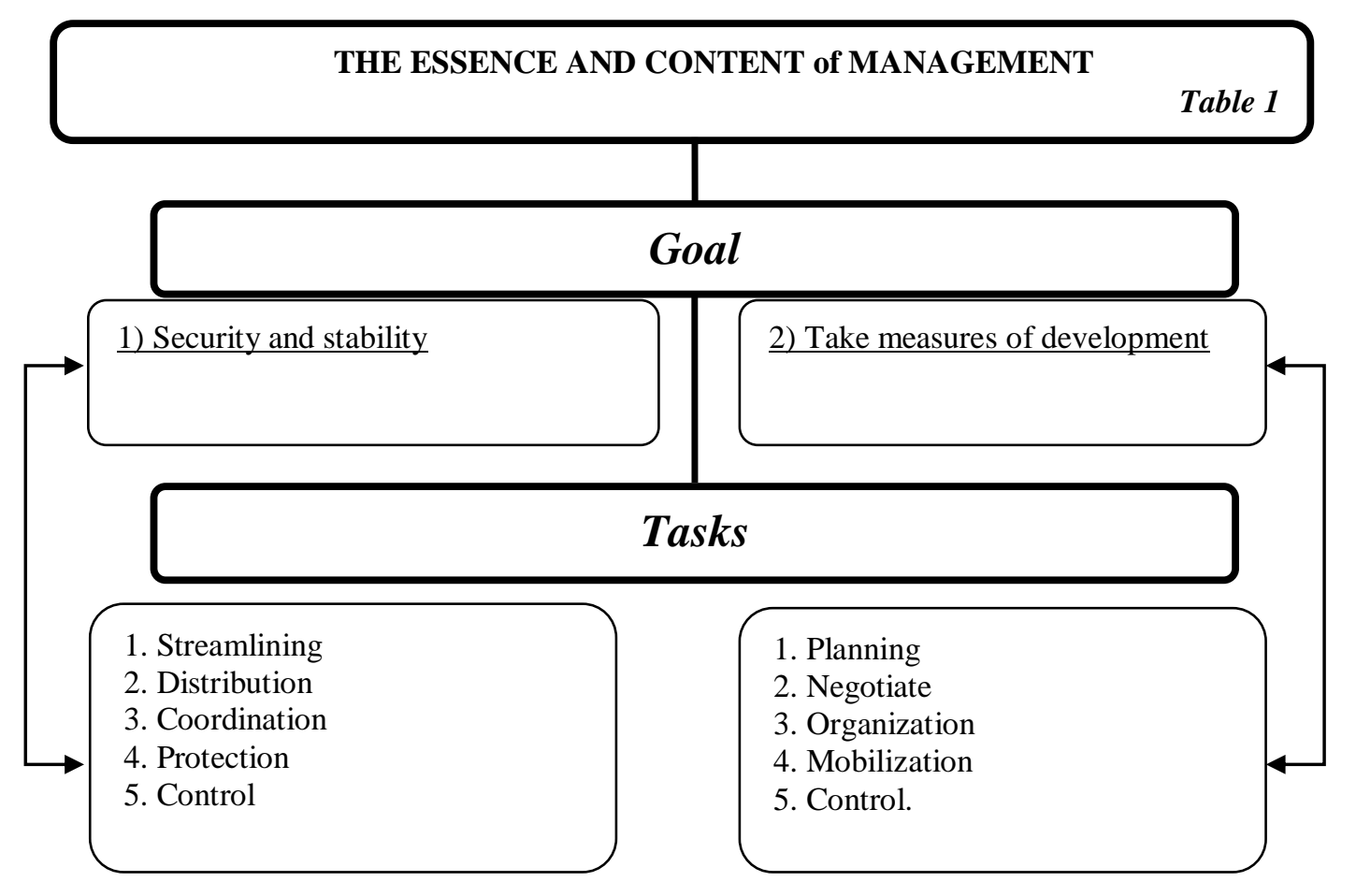

It is natural and logical would be when released two important management objectives: first, security and stability, and the second, the development of the system. In our opinion, the following words of the President of the Republic of Uzbekistan Islam Karimov, confirms this approach: "First, the first task is to ensure the security, peaceful accommodation, and then the second task is to develop the economy." [13]

Unfortunately, as mentioned above in the description of the management current scientific fields are typically based on its function (contents), and not on the target (the entity). Thus, we want to say that the management is a complex social and organizational activity, ensuring the existence, stability and security, and development, respectively, with promising targets.

It is expedient was, it would be, to determine the control functions on the basis of its nature. This gives a clear idea about what to do in certain circumstances, and to manage effectively (See Table 1).

\section{Tasks of management}

In our opinion, to ensure the security and stability - the primary goal of management is necessary to do the following:

1. Streamlining - to set regulations for ensuring the stability of relations within the public system, 


\begin{tabular}{|c|c|c|c|c|c|c|}
\hline Impact Factor: & $\begin{array}{l}\text { ISRA (India) } \\
\text { ISI (Dubai, UAE } \\
\text { GIF (Australia) } \\
\text { JIF }\end{array}$ & $\begin{array}{l}=1.344 \\
=0.829 \\
=0.564 \\
=1.500\end{array}$ & $\begin{array}{l}\text { SIS (USA) } \\
\text { PИНЦ (Russia) } \\
\text { ESJI (KZ) } \\
\text { SJIF (Morocco) }\end{array}$ & $\begin{array}{l}=0.912 \\
=0.234 \\
=1.042 \\
=\mathbf{2 . 0 3 1}\end{array}$ & $\begin{array}{l}\text { ICV (Poland } \\
\text { PIF (India) } \\
\text { IBI (India) }\end{array}$ & $\begin{array}{l}=6.630 \\
=1.940 \\
=4.260\end{array}$ \\
\hline
\end{tabular}

because if there is no order and discipline, and it will not be stable.

2. Distribution - is a worthy mission "master" problems facing the system, the distribution of existing resources. If this task is not performed objectively, there is a risk to security and stability, due to the emergence of social unrest. On this occasion, thinkers expressed this way: "The criterion of reasonableness leaders is a good knowledge of the basics of government, the distribution of tasks to people according to their experience and abilities". [14]

3. Coordination - means ensuring a consistent, interrelated activities to "public vehicle" is not pulled in all directions. For this reason, since ancient times in China there is a saying "The sequence creates management." [15] If you do not have the appropriate or relationship, then places poorly evaluated management activities.

4. Protection - in the broadest sense of the preservation of the system from external pressures and influences, actions that destroy its interests. If the previous functions have internal values, this function means the destruction of the negative aspects of impeding reform. Therefore, in the work of the Eastern thinkers have also not in vain: "I decided to control them so I owe them, to protect them is my duty." [16] The value of this function, in order to separate that if the subject of management in their activities will not be able to protect his subordinates, he will cause discontent, a control system, in this case there is a requirement to replace the specifics of control or subject. Therefore, the protection function is considered to be one of the key management tasks.

5. Control is a large-scale task management and important to monitor the specifics of the processes, to diagnose the state of the social structure and social element and on this basis to apply appropriate measures.

In order to ensure development in the management of the state is necessary to perform tasks of planning, discussing, organizing, mobilizing, controls that have common goals with the objectives of corporate governance. Attempts to merge between the public and corporate governance lies precisely in it. In this case:

1) Planning - the definition of a deep thought pondering the challenges facing the system, necessary tasks to achieve the prospects and designing activities for their implementation.

2) Negotiating - joining the process in agreement with the relevant parties in order to fulfill the tasks of the system.

3) Organization - a complex preparation of material and social resources to carry out planned, planned activities. If not ready, as it should, the measures planned may not take place. Sometimes, by the will of the case of ready resources accident occurs, but if not properly prepare for the applicable event, it is complicated to achieve the intended purpose.

4) Mobilizing - occupying an important place in the management carries out the planned work of the persons working on these effective measures (spiritual, ideological, moral, social and economic) the creation of an object, involvement in the creation.

\section{Conclusion}

Complex of this tasks that arise from the two main goals, help with a more complete understanding of this phenomenon. In turn, how these challenges leaders correctly applied, it depends on it, that the management will be productive or not productive.

\section{References:}

1. (1992) Upravlenie - ehto nauka i iskusstvo: A.Fajol', G.EHmerson, F.Tejlor, G.Ford. Moscow: Respublika, 1992. - pp. 9, 11-12.

2. Novikov DA (2015) Kibernetika: Navigator. Istoriya kibernetiki, sovremennoe sostoyanie, perspektivy razvitiya. - Moscow: LENAND, 2015. - 160 p. (Seriya «Umnoe upravlenie»). pp. 9.

3. (1991) Chelovek: Mysliteli proshlogo i nastoyashchego o ego zhizni, smerti i bessmertii. Drevnij mir - ehpoha Prosveshcheniya. /otvetstven. red. I.T.Frolov. Moscow: Politizdat, 1991. - pp. 27.
4. Tit Makcij Plavt. Osly. (1997) Sobranie sochinenij v 3-h tomah. T.1. - Moscow:"Terra", 1997. Perevod s latinskogo A.Artyushkova. Available: http://www.lib.ru/POEEAST/PLAVT/plavt1_1. txt (Accessed: 10.10.2016).

5. Jyldoshev S, et al. (2002) Yangi va ehng yangi davr Garbij Evropa falsafasi (XVII-XX asrlar). - T.: Shark, 2002. - pp. 19.

6. Kurbonova L (2009) Sharkona boshkaruv va millij yzlikni anglash. / Jamiyat va boshqaruv, 2009, №1. - pp.17. 


\begin{tabular}{l|lr|ll|ll} 
& ISRA (India) & $=\mathbf{1 . 3 4 4}$ & SIS (USA) & $=\mathbf{0 . 9 1 2}$ & ICV (Poland) & $=\mathbf{6 . 6 3 0}$ \\
Impact Factor: & ISI (Dubai, UAE) $=\mathbf{0 . 8 2 9}$ & PUHЦ (Russia) $=\mathbf{0 . 2 3 4}$ & PIF (India) & $=\mathbf{1 . 9 4 0}$ \\
& GIF (Australia) & $\mathbf{0 . 5 6 4}$ & ESJI (KZ) & $=\mathbf{1 . 0 4 2}$ & IBI (India) & $=\mathbf{4 . 2 6 0}$ \\
& JIF & $=\mathbf{1 . 5 0 0}$ & SJIF (Morocco) & $=\mathbf{2 . 0 3 1}$ & & \\
\hline
\end{tabular}

7. Abu Rajhan Muhamed ibn Ahmed al-Beruni (1963) Mineralogiya (perevod

A.M.Belenickogo) - T., 1963. -pp.31-32.

8. Gazzolij Abu Xomid (2005) Kimiyoi saodat: (Rux xakikati). - T.: Adolat, 2005. - pp. 89.

9. Koshifij Xusajn Voiz (2010) Ahloқi muxsinij ("YAhshi hulklar"). - T.: Uzbekiston millij ehnciklopediyasi” Davlat ilmij nashriyoti, 2010. - pp. 249

10. Navoij A (1991) Saddi Iskandarij: (nasrij bayoni bilan). - T.: G.Ghulom nomidagi nashriyot matbaa birlashmasi, 1991. - pp. 545.

11. Saidov AH (2008) Filosofsko-pravovoe nasledie Immanuilya Kanta i sovremennaya yurisprudenciya. - T.: Patent-Press, 2008. - pp. 76.

12. Politologiya: Olij ykuv yurtlari talabalari uchun kyllanma (S.Otamurotov, I.EHrgashev, SH.Akromov, A.Kodirov; Mas"ul muxarrir: R.Z.ZHumaev - T.: Uzbekiston, 1998. - pp. 130.
13. Karimov IA (2001) Vatan rаvnaқi uchun хаr birimiz mas"ulmiz. - T.9 - T.: Uzbekiston, 2001. - pp. 302.

14. (1994) Kalila va Dimna: (Xikmatnoma) S.Ganieva tarzhimasi; Nashr uchun mas"ul: H.Nazirov. - T.: Istiklol, 1994. - pp. 192.

15. (2001) Iskusstvo vlastvovat' / Li Gou. Plan obogashcheniya gosudarstva. Plan usileniya armii. Plan uspokoeniya naroda (XI v.). Perev. s kit. Lapinoj Z.G. Lyu SHao. O chelovecheskom sushchestve (III v.). Perev. s kit. Zinov'eva G.V. Seriya «Kanony». - Moscow: Belye al'vy, 2001. - pp. 180.

16. Otamuratov S (2015) Yoshlar siyosij madaniyatini rivozhlantirish omillari. - T.: “O'zbekiston", 2015. - pp. 17. 